\title{
PAREMIOLOGICAL CORRESPONDENCE AND ITS AFTER-THOUGHTS
}

\section{Outi Lauhakangas}

\begin{abstract}
Outi Lauhakangas had the privilege to communicate with academician Arvo Krikmann during the Finnish-Estonian project on common proverb types of the Balto-Finnic people, Proverbia Septentrionalia II. In the beginning of the project she was eager to ask, by e-mail, anything that seemed interesting for close differentiation and Krikmann was patient enough to answer her, often in thorough detail. Lauhakangas obtained a new approach to proverb types that differed from her routines for dealing with the international type-system of proverbs by academician Matti Kuusi. She had to look at proverbs and the motives for using them from a closer perspective. Could we really understand the situations and archaic mentality connected to some cryptic texts without any further information or supporting evidence given by authentic users? And on the other hand, how exclusive has the use of some proverbs originally been? Lauhakangas re-examines and reappraises the intensive paremiological correspondence from a temporal distance after some experience of proverb studies.
\end{abstract}

Key words: Arvo Krikmann, Balto-Finnic languages, classification of proverbs, comparison of proverbs

The material or object of this article consists of an interaction between an experienced paremiologist and an immature scholar. The matter that should generate a scientific article of this report derives from the questions arisen years after the original contact. The author had the privilege to communicate with academician Arvo Krikmann during the Finnish-Estonian project (19972000) on common proverb types of the Baltic people, entitled Proverbia Septentrionalia II. The comparison project was funded by the Finnish Academy. Background for this connection was a previous paremiological marathon that took place during the 1980s and yielded the first volume of Proverbia Septentrionalia consisting of nine hundred Balto-Finnic proverb types with Russian, Baltic, German and Scandinavian parallels and their analysis (Kuusi et al. 1985). Already in those times Krikmann belonged to the team of Finnish and Estonian paremiologists headed by academician Matti Kuusi. The first stage was a comparative edition of the most common proverbs of the Balto- 
Finnic peoples. But the challenge to compose a collection of the proverbs representing the less productive layers of Balto-Finnic proverb-lore activated Estonian researchers to restart the project.

Krikmann remarked in the forewords of his statistical analysis of the BaltoFinnic and non-Balto-Finnic materials in Proverbia Septentrionalia how provisional his conclusions actually were.

[...] a more comprehensive study of the internal and external relations in Balto-Finnic paremiology cannot obviously begin before the proverb repertoires of the Balto-Finnic peoples have been mutually compared in their entirety and equivalents have been found for the whole Balto-Finnic repertoire from the non-Balto-Finnic neighbours as well. (Krikmann in Kuusi et al. 1985: 29)

This ideal was a principle to which the author (from now on the first person singular of this article) did not, at first, pay sufficient attention. A possibility to concentrate on representative samples of the research material was excluded. An endeavour to process reliable data meant studying material as thoroughly as possible. For myself, the challenge would later be how to combine quantitative and qualitative research in paremiology.

\section{PROVERBS AS ACKNOWLEDGED LINES OF TRADITION}

Krikmann knew that the folklore archives of the Finnish Literature Society in Helsinki are famous for well organized collections of oral tradition. The same kind of completeness has been the aim in Tartu, in the Estonian Folklore Archives. In Finland, the archival collection of manuscripts includes around four million individual notes on folklore and oral tradition; a total of 535 meters of shelf space. In both countries the card files are an important instrument to ensure availability of amounts of archival material. One part of those card files referring to manuscripts of the folklore archives is coded indicating different genres of the so-called small size tradition. They consist mostly of proverbs but also stereotyped phrases, similes, wellerisms, witticisms, clichés and other proverbial phrases. In Tartu Krikmann had, in cooperation with Ingrid Sarv, edited a four volume collection of Estonian proverbs, Eesti Vanasõnad (1980-1988), consisting of 15,140 proverb types with their variations and a voluminous additional section. Earlier our scholars had also published a scale model of the archival proverb card files with 15,904 entries (without a complete demonstration of variations): Sananlaskut (Laukkanen et al. 1978). This 
was the state of affairs at the beginning of proverb research when I began to familiarize myself with this genre of small size tradition.

Classification of "surplus cards" of small size tradition was actually my first concern with the folklore archives of the Finnish Literature Society. In order to learn to understand how proverbs differ grammatically from other small size genres of folklore one should at first learn to pick out other genres from amongst them. Kuusi taught me to identify the genre of proverbs compared to other genres giving some useful recognition advice. That is actually the only practical way to approach this genre of folklore, if you have to content yourself with a single sentence which is totally in isolation from context information. Formerly the attitude towards collecting proverbs reflected a conviction that everybody in our culture knows, or at least should know, meanings of these expressions. The task to explain these was just optional and could be performed either by a collector or by an informant, in other words by any person who was clever enough to compose an explanation and could perhaps invent a general situation for their use. An important thing was to find out if proverbs collected for the archive were or were not genuinely oral tradition. The possibility to get material, copied from proverb collections, has always been a problem for paremiologists. On the other hand, the genre of proverbs has throughout its history been in constant movement being transferred from written texts to oral tradition and vice versa (Kuusi 1985: 72-84).

\section{PROVERB VARIATIONS AT CLOSE RANGE}

The point of departure of our second stage of the Balto-Finnic paremiological project was a database constructed according to Estonian proverb texts in a comprehensive collection thereof. During the correspondence between Krikmann and myself, concerning construction of proverb types, I was quite eager to enquire by e-mail about anything that seemed interesting. I became enthusiastic about hair-splitting and Krikmann was often patient enough to answer me in depth. I learned a new approach to proverb types that differed from my practice in dealing with the international type-system of proverbs which we had been constructing with academician Matti Kuusi. During his last years Kuusi had been orientated towards a search for quite general questions that would concern proverb-lore of the world. He saw that Finland is a convenient observation point for international comparison of proverbs, because it is situated on a small strip of the globe where it is permissible to demonstrate the cultural treasures of the nation as foreign loans (Lauhakangas 2001: 17). 
Entering the project of Balto-Finnic proverbs I had to look at proverb variation at close range. I had to admit the possibility to deal with items of our own culture or our cognate people yet often unable to make sense of those proverbs. Dealing with some cryptic proverb texts, known by a very limited number of people, I often asked myself if I could really reconstruct the situations and the archaic mentality connected to them. As mentioned above in connection with archive notes, either in Finland or Estonia, there is rarely any further information or supporting evidence given by authentic users. Normally, we read a list of proverbs and the district from where they have been collected. In spite of this fundamental barrier of incomprehension or perhaps just because of it I maintained my interest in people's motives for using proverbs (see the result of that in Lauhakangas 2004).

\section{QUESTIONS TO KRIKMANN ABOUT COMPARISONS OF PROVERB TYPES}

Right from the beginning of our proverb comparison work I wondered if it was possible for us to really understand the situations and archaic mentality connected to some cryptic texts without any further information or supporting evidence given by authentic users. I read Anna Leena Kuusi's report of Krikmann's notes about "Some Difficulties Arising at Semantic Classifying of Proverbs":

[...] proverbs which on the surface are either totally or only partly identical can be interpreted in many different ways at the semantic level. $\mathrm{He}$ [Krikmann] believes that structuralists have often been guilty of oversimplification in that they have selected only the "basic" or "most salient" aspects of the whole semantic information of the proverb as the basis of their analyses. (Kuusi [Siikala] 1974: 931)

I was especially interested how exclusive had the use of some proverbs originally been. Were there some proverbs that could be called spell-proverbs, others interpreted always completely literally and some which would have been mentioned only in certain situations? In October 1997, in the beginning of the process of our concrete choice situations, when handling proverb types, I encountered an interesting pair of proverbs which demonstrated alternatives for limiting a Balto-Finnic proverb type. The next two kinds of proverb texts (Finnish and Karelian/Estonian) were linked to represent the same proverb type in our new collection. 
Take the knife off the bread before you take the child out of the fire. (translation)

Finnish: Ennen veiht' leivän piältä kun laps tulesta.

Sooner correct the footstool, which is upside down than take a child out of the fire. (translation)

Karelian: Ennen ota skammi selältäh kun lapsi tulesta.

Estonian: Ennem vôta järg maast kui laps leest.

I wrote to Krikmann about my hesitation concerning the Finnish proverb type, because all of its occurrences contained the image of a knife on top of the bread. I saw that the bread proverb originated in folk belief. In former times, grain and bread were given the highest honour. Fresh bread was eaten completely by breaking it and this tradition in Finland originates, at the latest, with the arrival of Christianity: Jesus broke bread. If a knife was left on top of the bread, it was said that the devil will come and take away our bread and harvest luck from our house.

I did not know if there was a similar kind of prohibition rule concerning a footstool, järi (Estonian) or skammi (Karelian) when this item was found upside down. In Finnish folklore archives we only had one archival note from Viena Karelia referring to turning of a footstool. In the Estonian archive that proverb occurred six times.

My interest in beliefs and proverb-lore increased during our comparative research. I began to label some proverb types with an attribute 'folk belief'. But my brave task was scotched by the professor of Finnish language in Helsinki, namely paremiologist Pentti Leino, who stated curtly in one seminar that all proverbs can be considered beliefs. Thus I had to ask myself, was it at all important in this project to think about the origins of proverb images and how serious factors those might have been in people's world view. Should we rather concentrate on proverb types at the level of language means consisting of linguistic forms and images (like comparisons and hyperboles etc.)?

Krikmann answered my reflection, which can be compressed to one question: Are these few archival notes strong enough to create a common proverb type for three related languages?

Krikmann:

I think that when we have at least some kind of similar form in three national groups (Finnish, Estonian, Karelian), we should take this as a proverb type. This type could in general level correspond to the idea (similarly as an image to the hyperbole): better to take care of problems 
connected to a however trivial object than to hurry and worry about a child. We should join together the Finnish bread form (which is the largest one), the Estonian and Karelian footstool-form, the Estonian brushform etc. [...]

This example is actually quite interesting and also problematic in another way: What is the primary theme of that proverb type and what is its hyperbolic image? In the bread variant the bread is the theme and 'the child out of the fire' represents the hyperbolic image, whereas in other variants the theme is a child and the idea is that you shouldn't particularly take care of and fuss about a child and both a footstool and the brush stand for hyberbolic images. But as the lexical distance of each variant is so small, I wouldn't care about this kind of semantic nuance. It would be a pity to leave out the Finnish bread-variant? Wouldn't it?"

This swarm of expressions reminds me of another proverb, where a head of a pike is replaced by a fool's head etc. A pike's head and a log's head, a bream's head and a sheep's head (are alike). [The pun in original languages is how alike those heads sound]

E: Sia pia ja siia pia, hane pia ja hauvi pia.

F: Kuhan pä̈̈, - Juhan pää, hauen pää, - halon pä̈̈, siian pä̈̈sian pä̈̈, lahnan pää-lampaan pä̈̈, särjen pää-kärjen pä̈̈.

What is then the main theme?

In Estonian we have more of these exceptional examples:

Women's anger and southeasterly wind will not stop until water comes (rain and tears).

Naiste viha ja vesikaare tuul äi jäta enne järge, kut vesi lahti. (Eesti Vanasõnad, No. 7299)

There are variants inside this type in which, against all expectations, a named WIND (morning wind, southeasterly, south-west wind etc.) is the point, not the anger of a woman. They may be secondary and whatever but in principal these kinds of inverse cases are obviously possible. [...]

My present attitude towards the above described formulation of the problem reflects my improved knowledge about functions of proverb use in general (Lauhakangas 2004). I would no more worry as much about the etymology of proverb texts. The 'bread and knife'-proverb does not straightforwardly illustrate any authentic behaviour of ancient Balto-Finnic peoples, rather the us- 
age of these hyperbolic expressions reminds the hearer (and the speaker him/ herself) of the importance of respecting common values. The habit of using these kinds of expressions tells about togetherness. It represents the common knowledge of a group. In a way it does not matter how seriously or jokingly these proverbs have been and are used in everyday situations, for example, are they explaining one person's own superstitious behaviour or just a sense of humour. They may function in any case.

On 31.10.1997 I write to Krikmann:

Every now and then I meet interesting proverb types. One of them is this: Never part with a road or an old friend. [Maantiest ja vanhast ystäväst ei pie erota. Vanhast maantiest ja vanhoist neuvoist pitää ottaa vaar. 13 Kivennapa 1935, Kivennapa 1956. H 1490, NH 40, SL 6093, 14287. Vanhas t'ies da vanhas ystäväs ei pie erota. KS 12168. Vana sõber ja vana tee pea kinni. Vana tee, vana sõber. 14 EV 13490, 13497. Vanhasta ystävästä(h:6,s:1,t:1)/Parhaasta ystävästä(f:1)/Maantiestä, ystäväsẗ̈(h:2) /Vanhasta maantiestä(h:2). Alte Freunde und Wege soll man nicht verlassen. Gamla vägar och gamla vänner svika inte gerna. (Düringsfeld et al. I 1872: 62)]

Checking the Matti Kuusi international type system of proverbs (Lauhakangas 2001) shows that the proverb I was asking about is the type M2a 15. Its idea is quite global (European, Islamic, Orient), only Sub-Saharan African equivalents are missing. Compatible proverbs from different parts of the world are loosely coordinated in this classification. This time the location of the proverb bases on the quite concrete theme 'mobility and travel' in the main group M: 'coping and learning'. The detailed subject of the proverb group is M2a: 'choosing one's route, the dangers of a journey'. An alternative location for this proverb type is $\mathrm{H6a}$, a sub-group of social interaction. It deals with the relationship between friends, enemies or good or bad neighbours and especially with the value of a friend or significance of an enemy.

My question to Krikmann specifies a variation that we have in Finnish material but which is missing in Estonian material: You should never go far away from the Word of God and the country road post. Thus I continue:

Inspecting your Eesti Vanasõnad numbers 13490 and 13497 a question arose: Do you have at all comparison of 'old safe road' and 'Word of God'? In our material 'the old friend - old road' combination is most well-known in Southern Karelia (10 of all 13 archival notes), but elsewhere 'the high- 
way and Word of God' is more common. (I am not going to join these to the same type.) Or have you probably had censorship concerning this kind of motives in Estonia? [...]

To this question Krikmann answered immediately:

Unfortunately I don't really know any Estonian material comparable to 'old road' and 'Word of God'. Neither did I find it in the Matti Kuusi type system of proverbs. (Or maybe I didn't search carefully enough), so that it is not among international and grand languages.

Censorship cannot be the reason. In the three books of Eesti Vanasõnad we have had only one proverb text taken away: Better to become eaten by our own dogs than by wolves of Russia (EV 11230). And even if it was once deleted, it has already been taken back a long time ago. This sentence has not simply come to us. All in all, the theme of God is not very productive in the Estonian material. [...]

It is true that 'Word of God' version is not international and it is understandable that Krikmann did not find that variation, although an old road compared to trusting to the Word of God is actually included in the Matti Kuusi type system. Anyhow, the international type is much looser than in the Proverbia Septentrionalia II; it is more based on family resemblance.

\section{COMPLEXITY OF INTERPRETING PROVERB INFORMATION}

I became properly oriented towards paremiologic discussion of the 1970s only afterwards - not even during those few years when I worked in practice with Arvo Krikmann, Anne Hussar, Rein Saukas and Pekka Hakamies; when I jumped into the restart of the Proverbia Septentrionalia (Matti Kuusi et al. 1985). Only now am I ready to understand Krikmann's principles concerning proverb classification, proverb types etc.

Krikmann puts forward the view that proverbs which on the surface are either totally or only partly identical, can be interpreted in many different ways at the semantic level. He believes that structuralists have often been guilty of oversimplification in that they have selected only the "basic" or "most salient" aspects of the whole semantic information of the proverb as the basis of their analyses (Siikala [Kuusi] 1974: 931). 
Already in the seventies a semiotic approach, represented by Ágnes Szemerkényi (1974: 934-936), was based on the view that proverbs operate as a code reflecting social life and values. Her view was criticized in the Symposium on Paremiology in Helsinki at that time. From the point of view of research at present I find her thoughts ahead of the times. She saw the pragmatic function of the proverbs as the most important level - primus inter pares - in the proverb analysis. But Szemerkényi's claim that proverbs could not have an entertaining function seems to be misleading, according to my observations. Naturally, there are differences of emphasis on different functions of proverb use between world cultures.

Kuusi used to play with a thought that Mediterranean cultures could resemble our Baltic cultures on the coasts of an inland sea. For example in Malta, Dr. Aquilina, in his time, compared the impact of Arabic and other cultures on Maltese proverbs. This would be a hypothesis to test how proverbs live and are loaned inside a bounded region with active contacts.

\section{THOUGHTS AROUSED BY OUR WORK ON CLASSIFYING AND TYPOLOGIZING PROVERBS}

When a paremiologist wants to discover the deepest essence of the proverb, he/she thinks that he/she has to concentrate on a phraseological unit and ought to cover by definitions the challenge called 'the proverb' consisting of elements from cognitive science, linguistics, social psychology, anthropology, social history and folkloristics. An ideal solution within these limits would be success in linking the title of the basic text of any proverb type, picked from the folklore archives and literature in addition to linguistic genre definitions like structural (metric, stylistic, rhyme-related), content specific (thematic and basic opposition characteristics) also appraisal of their modality, to the relationship between the surface level and the semantic deep level and all the attributes concerning the real and imaginable contexts. The scholar should be able to define every situation possible for each proverb-type, to draw a historical and regional profile for every proverb-type, to consider the variety of local dialects and jargons, attend to restrictions according to the sexual genre or social position of the most common user, to make a note of the infrequent use of some proverbs and even personal differences that informants may have brought to the interpretation of any proverb variation. 
If we persist in defining the proverb as a special phraseological unit or concept, which has several sub-concepts and if we at the same time try to take into account all possible things concurring to its polysemy and multifunctional character, we soon find ourselves entangled in detailed definitions. That was the case at least in Permyakov's classification system. In order to apply, in an orthodox manner, this kind of criteria, e.g. the international proverb corpus turns out to be practically oversized even by means of the most advanced information processing and multimedia. And what is more important, in my opinion, the multiple characterizing of proverb types is in principle a misleading approach.

The crucial thing, that Archer Taylor (1931) called the intuition of scholars to recognize a proverb as a proverb, will mostly be explained by our own experience and preparedness to understand the social and interactive potential of a proverb - even the first time we hear or read it. I claim that in order to understand the multifunctional proverb use and polysemy of proverb texts we have to pay attention to more general cultural, cognitive and social psychological aspects of human interaction. Outside of the collections proverbs always function in practical situations and in internalized social interdependency. They are lines, statements or merely internal talk to oneself, whatever their form might be: spoken, depicted or written, seen or heard, influencing or merely imaginary effectiveness.

I propose that the paremiological focus should be in a cultural or global phenomenon called the proverb instead of a separate linguistic or literal-historical and stylistic entity (a special phraseological unit) or a cluster of attributes. Thus, it could be easier to bear in mind that it is always people that enact and reproduce proverbs, only people maintain this cultural phenomenon as a part of their interaction. We feel a liking for proverbs or we can detest or, of course, disregard them. We decline to humanize or at least objectify our instruments. We may see some proverbs through their uniqueness or as a part of our own history, our own property. This is really part of the phenomenon called the proverb. Still, if we deal with proverbs as entities, we can estimate how much and how extensively they are used, how openly or darkly, how consciously or unconsciously they are used. They are examined as instruments to oppose or support. Some of them are utilized to recall an important person who uttered them. If we speak about them as single entities, we can demonstrate how they are twisted or even tormented. All our attraction or action towards proverbs is, however, part of the cultural phenomenon called the proverb. Although proverbs can easily be treated as characters or objects, collector's items, you can neither reduce their meaning to their wordings and structures nor to a sum of individual interpretations. 
Pointing out the importance of studying social interaction and cognitive processes within paremiology does not exclude work on the history of proverb use, their popularity or redundancy, statistics of their occurrences in literature and media, linguistic mobility, transitions and conversions, or their being sources of creativity. This does not exclude the need to collect proverb texts of different cultures and getting information by comparing these items. My aim is rather to examine the frequently repeated claim that proverbs should be studied in their contexts in order to understand them. I want to broaden this claim to comprise not only textual study, but I would like to see more discussion on alternative ways to study the use of proverbs in everyday social contexts in different cultures.

\section{REFERENCES}

Aquilina, Joseph 1972. A Comparative Dictionary of Maltese Proverbs. Malta: The Royal University of Malta.

Düringsfeld, Ida von \& Reinsberg-Düringsfeld, Otto von 1872-75. Sprichwörter Der Germanischen Und Romanischen Sprachen Vergleichend Zusammengestellt I-II. Leipzig: Hermann Fries.

Eesti Vanasõnad I-IV 1980-1988. Compiled by A. Hussar \& A. Krikmann \& E. Normann \& V. Pino \& I. Sarv \& R. Saukas. Edited by A. Krikmann \& I. Sarv. Tallinn: Eesti Raamat.

Krikmann, Arvo 1974. Some Difficulties Arising at Semantic Classifying of Proverbs. Proverbium, Vol. 23, pp. 865-879.

Kuusi [later Siikala], Anna-Leena 1974. Paremiology searching its way. Proverbium, Vol. 24, 930-931.

Kuusi, Matti 1985. Perisuomalaista ja kansainvälistä. Helsinki: Suomalaisen Kirjallisuuden Seura.

Kuusi, Matti et al. 1985. Proverbia Septentrionalia. 900 Balto-Finnic Proverb Types with Russian, Baltic, German and Scandinavian Parallels. Folklore Fellows' Communications 236. Helsinki: Academia Scientiarum Fennica/Suomalainen Tiedeakatemia.

Lauhakangas, Outi 2001. The Matti Kuusi International Type System of Proverbs. Folklore Fellows' Communications 275. Helsinki: Academia Scientiarum Fennica/ Suomalainen Tiedeakatemia.

Lauhakangas, Outi 2004. Puheesta ihminen tunnetaan. Sananlaskujen funktiot sosiaalisessa vuorovaikutuksessa. [The functions of proverbs in social interaction]. Suomalaisen Kirjallisuuden Seuran toimituksia 1001. Helsinki: Suomalaisen Kirjallisuuden Seura.

Laukkanen, Kari \& Hakamies, Pekka 1978. Sananlaskut. Helsinki: Suomalaisen Kirjallisuuden Seura. 
Permiakov, Grigori L. 1979. From Proverb to Folk-Tale: Notes on the General Theory of Cliché. Moscow: Nauka.

Szemerkényi, Ágnes 1974. A semiotic approach to the study of proverbs. Proverbium, Vol. 24, 934-936.

Taylor, Archer 1931. The Proverb. Cambridge, MA: Harvard University Press. 